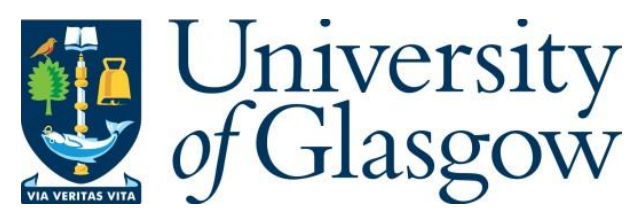

Aliyev, H. (2015) Examining the use of informal networks by NGOs in Azerbaijan and Georgia. Journal of Civil Society, 11(3), pp. 317-332.

There may be differences between this version and the published version. You are advised to consult the publisher's version if you wish to cite from it.

http://eprints.gla.ac.uk/153380/

Deposited on: 11 December 2017

Enlighten - Research publications by members of the University of Glasgow

http://eprints.gla.ac.uk 


\title{
Examining the Use of Informal Networks by NGOs in Azerbaijan and Georgia
}

\author{
HUSEYN ALIYEV \\ Research Centre for East European Studies (Forschungsstelle Osteuropa) at the University of Bremen, \\ Bremen, Germany \\ Correspondence Address: Huseyn Aliyev, Research Centre for East European Studies (Forschungsstelle \\ Osteuropa) at the University of Bremen, Bremen, Germany; Email: aliyev@uni-bremen.de
}

\begin{abstract}
To date little is known about the non-governmental organizations' (NGOs') use of informal networks, contacts and connections, as well as about the 'informalization' of postcommunist civil society in the former Soviet Union. Research on the subject has been mostly restricted to the study of civil society organizations (CSOs) in Central Eastern Europe, the Balkans and Russia, leaving the use and significance of informality among the South Caucasus's NGOs largely ignored. Drawing on qualitative in-depth elite interviews, this study examines the importance of informal networking within the NGO sectors of post-Soviet-rule Azerbaijan and Georgia. The findings of this study document that in Azerbaijan and Georgia, the practices of using informal networks of relying on patron-client relations with donors, and of individuals using their positions within organizations for profit making are widespread among the NGOs included in this research.
\end{abstract}

KEY WORDS: Informal networking, informality, NGOs, post-communist, civil society, South Caucasus, clientelism

\section{Introduction}

The break-up of the USSR in the early 1990s encouraged the development and proliferation of independent civil society ${ }^{1}$ across the former Soviet Union. Lavishly funded by Western donors, non-governmental organizations (NGOs) began mushrooming across the post-Soviet space, occupying all areas of social, cultural, and political life. A considerable amount of research has been published on civil society in the former Soviet Union (Henderson, 2002; Howard, 2003; Hemment, 2004; Evans et al., 2006; Uhlin, 2006). These studies have focused on the weakness of civil society (Howard, 2003), challenges to its development (Henderson, 2002), operational and organizational features of civil society organizations (CSOs) (Hemment, 2004), the relationship between the civil sector and democratization (Uhlin, 2006), as well as on many other aspects of civil society associations in post-Soviet spaces. However, little is known about the widespread role of informality-here defined as the a sum of activities occurring outside of the formal public sphere, including, but not limited to, informal networking, social capital, and informal economic activities - and the influence of informality on the conduct of official business by the NGO sector in post-Soviet-rule countries. Although a voluminous body of research has been produced on the importance of post-Soviet informality for political and economic institutions (Round \& Williams, 2010; Ledeneva, 2013; Williams 
et al., 2013; Morris \& Polese, 2014), there have been few empirical investigations into the role of informal networking ${ }^{2}$ among post-Soviet NGOs. Apart from the published work of Gibson (1998), Howard (2003), and Aliyev (2014a), there is a general lack of empirical research on the relationship between informality and the post-Soviet NGO sector. Moreover, even these few existing studies have primarily focused on the relationship between informal networking and participation in civil society by the general public, rather than on the far more complex and ambivalent role of informality within NGOs. Attempts to investigate the use of informal networks by NGOs in post-communist Central Eastern Europe and the Balkans were made by Böröcz (2000) and, more recently, by Grødeland and Aasland (2011). Both studies have demonstrated that, irrespective of liberalization, organizational strengthening, and the increase in operational capacity of post-communist NGOs across the non-Soviet former socialist bloc, informal channels are 'indeed widely used by NGO representatives' (Grødeland \& Aasland, p. 129). Grødeland and Aasland (2011, p. 156) conclude that 'informal practice affects NGOs in much the same manner as it affects other sectors of society'.

In the post-Soviet context, according to the existing scholarship on civil society, problems such as state intervention in the work of NGOs (Ishkanian, 2008; Aliyev, 2014a, p. 266), the growth of government-organized non-governmental organizations (GONGOs) (Uhlin, 2006, p. 22; Evenson, 2007), rampant unemployment, systemic corruption, high levels of institutional distrust (Rose, 1994), low levels of popular participation in civil society, and the general failure of democratization (Bunce, 2003) continue to severely weaken the performance of the NGO sector. Along with these problems, the spread of informality and the importance of informal practices in the daily life of populations are problems that have been known to exist on a much greater scale in post-Soviet countries than in other post-communist regions (Miller et al., 1997; Rose, 2000). This all leads to the main research question of this study: What is the role of informality and, in particular, of informal networking within the post-Soviet NGO sector?

Both the weakness of civil society and the importance of informality are typical characteristics of nearly all non-Baltic, former Soviet states. Nevertheless, two case studies examined by this article - the NGO sectors of Azerbaijan and Georgia - serve as particularly interesting laboratories for the analysis of informal networking within the NGO sector. Both of these post-Soviet countries have similarly low popular participation in civil society, ${ }^{3}$ and the NGO sectors of both countries are affected by rather similar organizational and operational deficiencies (Nodia, 2005; Ishkanian, 2008; Aliyev, 2014a). Georgia's NGOs experienced a boom in development following the 2003 'Rose Revolution', which attracted higher volumes of international funding and attention. By contrast, Azerbaijan's NGO sector, following the entrenchment of authoritarianism in that country, has been plagued by an increase in the number of GONGOs and weakened by the stiffening of the government's control over independent civil society. In Azerbaijan, the lack of democratic transformation and the continuity of the Soviet legacy in formal institutions have further encouraged the growth of informal networks within formal institutions and cemented the importance of informality in the conduct of official business (Guliyev, 2012; Safiyev, 2013). In Georgia, a number of comprehensive institutional reforms implemented after the 'Rose Revolution' by Mikheil Saakashvili's government have helped the country to achieve modest success in decentralizing and modernizing Georgia's formal institutions, encouraging the growth of independent civil 
society, and undermining the importance of informality (Engvall, 2012; Aliyev, 2014b). This article focuses on Azerbaijan and Georgia because these two case studies make the 'most different' cases (Burnham et al., 2008, p. 74). The inherent differences between the NGO sectors of these two South Caucasian neighbours make them intriguing case studies of the relationship between informality and civil society.

The main objective of this study is to investigate the role of informal networks - the use of contacts, connections, and favours - within the contemporary NGO sectors of Azerbaijan and Georgia. More specifically, this article examines how, when, and why NGO officials and representatives rely on informal networking rather than on official channels. It also explores - as part of the 'informalization' of the NGO sector-the patron-client relations between NGOs and their donors, and the use of their positions within organizations by NGO representatives for private profit-making.

\section{Methodology}

This article builds upon findings from a series of semi-structured, in-depth interviews conducted in Azerbaijan (Baku), Georgia (Tbilisi), and Belgium (Brussels). The data were collected through qualitative interviews with elite informants interviewed throughout 2013 and 2014 either in person or over Skype and telephone. ${ }^{4}$ The interviews were based on open-ended questions and structured as semi-formal discussions. Interviews were carried out in English, Russian, and Azerbaijani. Three types of informants were interviewed for the purpose of this study. Firstly, a total of 35 interviews were conducted with senior NGO officials - founders of NGOs, executive managers, board members, and directors-working in Azerbaijan and Georgia. Secondly, 43 interviews were carried out with NGO representatives employed at different levels of administration within organizations operating in these two South Caucasian countries. Thirdly, the final group of interviews (a total of eight) were carried out with two senior European Union (EU) officials, four representatives of European civil society organizations working with local NGOs in Azerbaijan and Georgia, and two leading experts on civil society in the South Caucasus who were based in Brussels.

Informants from the first two groups of participants were selected from 15 NGOs based in the Georgian capital, Tbilisi, and from 14 NGOs based in the Azerbaijani capital, Baku. All selected NGOs are local civil society organizations (CSOs), which, along with their headquarters in the capital cities, also maintain offices across their respective country of origin and regularly implement projects in more than one geographical location of that country. The sample includes a variety of organizations working on political, cultural, social, environmental, and human rights issues. Each of the selected NGOs employs from six to more than 20 full-time staff members and a contingent of part-time volunteers. Given the spread of GONGOs in the region, and in Azerbaijan in particular, efforts were made to ensure that all selected organizations are independent NGOs. The sample selection criteria, apart from the focus on independent NGOs only, was also based on selecting NGOs permanently engaged in the implementation of projects, conducting awareness campaigns, and cooperating with international donors on a regular basis. Informants who were NGO officials and NGO representatives were asked to elaborate on (1) the use of informal networks by their own 
organization and by other NGOs operating in the country, (2) the informal relations between NGOs and donors and political actors, as well as on (3) other informal aspects of NGO work. Due to the sensitive nature of the topic of informality within NGOs, this project encountered high refusal rates among the original sample of over 200 informants, and therefore, the number of individuals who agreed to be interviewed remained low. Yet, due to the relatively low number of actively functioning independent NGOs in both countries, ${ }^{5}$ the author believes that the current sample size is fairly representative with regard to the relevant opinions and views prevalent within the NGO sectors of Azerbaijan and Georgia.

The survey informants who make up the third category were identified from a search of the published literature and information available on the Internet and were selected based upon their relevant work or research experience. This category of participants was chosen for the participants' knowledge of the use of informal networking by Azerbaijan's and Georgia's NGOs during their contacts and cooperation with international donors. Because of the limited number of representatives in this category and the high refusal rates of the European elites to discuss informal relations occurring between their organizations and NGOs in Azerbaijan and Georgia, only eight informants made themselves available to be interviewed.

\section{NGO sectors in Azerbaijan and Georgia}

The first non-governmental organizations appeared in the South Caucasus soon after the official collapse of the USSR in 1991. In less than a decade, their numbers expanded from several dozen groups to thousands of organizations registered in each country. For instance, according to official estimates, by 2012 the number of registered NGOs in Azerbaijan reached 2,850 (USAID, 2013, p. 31). ${ }^{6}$ In Georgia, several thousand NGOs were operating throughout the country at the end of the 1990s (Nodia, 2005, p. 14); by 2012, over 17,200 NGOs were legally registered in the country (USAID, 2013, p. 81). However, regardless of the increase in the number of NGOs, many organizations exist as 'on-paper-only' NGOs. Hundreds of such NGOs do not have offices or staff and exist only as names in official registers. Many more of these organizations consist of a single person, who functions as the founder, director, and the sole staff member of the organization.

Despite similarities in their organizational and operational structures, ${ }^{7}$ the NGO sectors of Azerbaijan and Georgia - largely due to political developments in their respective countries - have followed rather different pathways. In Azerbaijan, with the start of Heydar Aliev's presidency in 1993, independent civil society has been continuously persecuted (Abbasov, 2010; Diuk, 2012). The majority of NGOs suppressed by the government were specifically political or human rights organizations, but restrictions on civil rights and the free press have continued to negatively affect the development of the NGO sector in general. After the controlled succession of power from ailing Heydar Aliev to his son Ilham in 2003, the government's attempts to silence independent civil society intensified. In Abbasov's (2010, p. 13) words, Azerbaijan's NGO sector was 'gradually becoming the main target of government attacks'. Along with attacking independent NGOs, the Azerbaijani state has struggled to create its own state- 
controlled civil society. With the establishment of the Council on State Support to NGOs in 2008, which allocates on average US\$2.5 million a year on financing GONGOs in Azerbaijan (Abbasov, 2010, p. 15), the number of government funded and controlled civil organizations began to increase. Civil movements, similar to Russia's pro-regime youth organization Nashi and the Soviet Komsomol, began appearing in the country (Diuk, 2012). ${ }^{8}$ Talking about civil society in Azerbaijan, one interviewee lamented that ' $[\mathrm{t}]$ here is no middle way; you have to be either with the government, or against it, which defeats the point of NGOs: they are not supposed to be enemies of the state'. ${ }^{9}$ A senior EU official overseeing joint EU-Azerbaijani NGO projects echoes that opinion, adding that in 'Azerbaijan [it] is difficult for us to implement anything because the government is not very keen on NGOs. So we need to build up a [informal] relationship with the government.' 10

The Georgian NGO sector during the first post-communist decade, similar to Azerbaijan's NGO sector, faced continuous persecution from the government. First during the nationalist government of Zviad Gamsakhurdia and then under the regime of the old-school leader of Soviet Georgia, Eduard Shevardnadze, Georgian NGOs were monitored by the state and had limited opportunities for independent advocacy. Although Shevardnadze's rule was more benevolent to civil society than Aliev's in neighbouring Azerbaijan, Georgian civil society experienced few positive developments during the 1990s (Khutsishvili, 2009). Georgia's 'Rose Revolution' - one of the so-called 'colour' revolutions challenging post-socialist authoritarian regimes in Eurasia during the 2000s resulted in the overthrow of Shevardnadze's regime. Although the Rose Revolution was initially seen as an uprising of civil society against authoritarianism (Demes \& Forbrig, 2007), the pro-Western regime of Mikheil Saakashvili, brought to power by the Rose Revolution, was later accused of manipulating the NGO sector (Khutsishvili, 2009). As stated by an informant in Georgia, '[Considering] civil society after Saakashvili came to the government, vocal and critical ones are always associated with, or belong to, political parties, especially the ones who are critical. If you criticize Saakashvili, you will belong to the opposition.' 11 Nevertheless, the liberalization of NGO laws, which accompanied democratic institution-building and the efforts by the government to promote the development of civil society, has helped to strengthen Georgia's NGO sector. ${ }^{12}$ The victory of the Georgian Dream coalition, first at parliamentary elections in October 2012 and then at presidential elections a year later, has marked the first democratic transition of power in the post-Soviet history of the South Caucasus region. As of 2015, the current Georgian government continues to pursue liberal policies with regard to the NGO sector, encouraging the development of independent NGOs and promoting civil liberties.

This brief overview of the Azerbaijani and Georgian NGO sectors demonstrates that apart from their apparent similarities, the NGOs of these two countries operate in markedly different political environments. Thus far, however, there have been no studies which have tried to examine the role of informal networks within their NGO sectors. Having presented the brief overview of the present-day Azerbaijani and Georgian NGO sectors, this study presents an analysis of empirical findings on the use of informal networks and other forms of informal relations within the NGO sectors of these two South Caucasian countries. 


\section{Use of informal networks}

In-depth elite interviews conducted with NGO representatives in Azerbaijan and Georgia reveal that the use of informal networks - personal connections, contacts, or kinship ties - within the NGO sector is widely practiced by civil society organizations in both countries. Reliance on informal networks in the work of other institutions is well documented (Dershem \& Gzirishvili, 1998; Belli et al, 2004) and is a practice perceived positively by those interviewed in previous research. Similarly, the use of informal networks in the work done by NGOs in Azerbaijan and Georgia is perceived positively by the NGO officials and representatives interviewed for this article. Using private networks in their day-to-day work - dealing with state officials, collaborating with other NGOs, securing funding from donors, receiving donations from philanthropists, or paying their employees for their services - is seen by NGO leaders as instrumental to and indispensable for the success and survival of their organizations.

The percentage of interview participants in Georgia who admitted using informal networks regularly in their work, or who believed that informal networks are important, is not significantly different from the percentage of interview participants in Azerbaijan who answered the same questions (see Table 1). Although the overall reliance on informal networking appears to be greater in Azerbaijan than in Georgia, the gap between the two cases is insignificant.

Table 1. Use of informal connections and contacts within NGO sectors in Georgia and Azerbaijan

Over $90 \%$ of the informants interviewed in Azerbaijan, and over $80 \%$ of those interviewed in Georgia confirmed that their organizations regularly rely on informal networking in dealings with government officials. Building and maintaining informal relationships with state officials seem to be particularly important for those NGOs which have to work with state institutions on a regular basis. While over the past decade Georgia's relatively effective anti-corruption campaign has succeeded in reducing the instances of petty bribery in state institutions (Börzel \& Pamuk, 2011), Azerbaijan's efforts have been less effective and its institutions are still plagued by systemic corruption and the prevalence of informal gift-giving. Material or monetary gift-giving (hormet) offered in return for preferential treatment in formal institutions, and the use of connections, 'people of the circle' (adamimiz), are widely practiced by Azerbaijani state officials (Safiyev, 2013). The relations between state institutions and the NGO sector appear to be no different. As one interviewee from Azerbaijan put it:

When we work on projects which involve cooperation with government institutions, or which require [obtaining] ... permits from officials, using personal contacts is absolutely important. Even to pay a bribe, you first need to access officials [via private networks]. They won't talk to you unless somebody trusted recommends them to you. Then, they know it is safe for them to work [accept unofficial payments] ... with you. You also need to foster these [informal] relations ... inviting them [state officials] to banquets, offering them gifts and fraternizing [with them] as much as possible. Once you become their 
trusted person - adamimiz - you can get all kinds of favours easily, sometimes even without having to pay for them - it is easy to implement projects and you can do what others [international NGOs] cannot. ${ }^{13}$

In Georgia, although the Saakashvili-era reforms have weakened the culture of giftgiving and bribery in formal institutions (Aliyev, 2014b), the reliance on informal connections and networks (natsnoboba) still appears to be crucial for the daily work of NGOs. In the words of an NGO official from Georgia:

If I do not rely on my friends, relatives, and colleagues, I will never be able to pay taxes, pay the rent [for the office space], compete for grants, or implement projects. This entire society functions on [informal] networks. It is impossible for a non-profit organization to survive without relying on connections. ${ }^{14}$

Another informant, employed at a Georgian NGO, explained that the use of contacts is essential for an NGO's effectiveness and survival, and that informality within the NGO sector is a natural phenomenon because 'NGOs [officials] they all know each other and the staff of each NGO are people who all studied together or know each other. They are in-group members. It [NGO sector] is all closed. ${ }^{15}$ In Azerbaijan, as stated by a number of informants, some NGO founders and directors are close friends, or even members of the same kinship network. In consequence, exchanging favours and sharing resources through informal networks is a common practice for many NGOs.

As detailed by interview participants in both South Caucasian countries, many NGOs are founded by influential individuals: some NGO founders are well-known businessmen, others are distinguished artists or representatives of cultural elites, and many more are either retired or active politicians. Since being a founder and an 'owner' of a civil society organization is perceived as both beneficial for one's public life and charitable, many well-known individuals established NGOs to bolster their prestige. As noted by an NGO official in Azerbaijan:

These days all you need to create an NGO is proper connections and a bit of money, although connections are perhaps more important than money. If you know people - influential people ... who would help you to set up an [civil society] organization, it is all you need in this business. ${ }^{16}$

Creating a new NGO might be easy to do with the right connections, but according to an NGO official in Georgia, 'only about five percent ... on average survive through their first year'. As the official further observed, to establish an effective and sustainable NGO with the potential to become an influential NGO, 'one must have some sort of leverage'. For instance, as a senior EU official working with local NGOs in Tbilisi mentioned:

My main observation was that the NGOs [in Georgia] evolved around personality, around some big name, and organizations were referred to by the name of their founder or head. It was very indicative of the Georgian society; organizations evolve around the personality rather than issues. ${ }^{17}$ 
A similar observation was made by a director of a local NGO in Tbilisi, who said he believed that

Civil society in Georgia is very personalized. Many organizations are one man, or family-based, or friend-based, no membership, no fundraising, no organizational structure, no leadership rotation; and that is something that we are trying always to highlight to donors: that one of the requirements for an NGO that gets funding is that there should be some sort of governance, and most desirably, democratic governance, some sort of collegial body, some sort of rotation of staff. Yet, most organizations don't have that. ${ }^{18}$

Another NGO representative in Georgia explained that '[f]or many of these people [founders of NGOs], to create an NGO is no different to, let's say, open a shop, or to buy a car'. ${ }^{19}$ A similar opinion on the motives of NGO founders was voiced by an NGO representative who observed that

They [founders of NGOs] usually say that "I have an NGO", because they think of it [organization] as of their property and they use it ... [NGO] to improve their position in the society. They use it to acquire new powerful friends and connections with politicians and business people. The actual aims and objectives of the NGO are of secondary importance. ${ }^{20}$

However, even for those NGO officials who genuinely pursue the goal of providing the beneficiaries of their organizations with public goods and services, relying on informal networks is absolutely essential for securing funding and for collaboration with local partners. For instance, an informant in Azerbaijan stated:

Many of the EU's and USAID's grant projects require NGOs to collaborate with other NGOs on joint projects ... in order to apply for funding. You cannot apply for such grants as a single organization - you need to have partnerships with other NGOs, and then you apply as a group. Yet, many NGOs have no desire of sharing the grant with [unknown] organizations and they prefer to strike strategic alliances with NGOs run by their friends or acquaintances. ${ }^{21}$

Use of informal connections is also crucial in securing donations and contributions from philanthropists. Indeed, personal networks and the big name of an influential NGO founder/director in many cases serve as the most important criteria for receiving such donations. For example, one interviewee in Georgia cautiously confessed that ' $[t]$ he main reason our NGO receives all these contributions [from wealthy businessmen] is because they all are friends or acquaintances of Mr. X [NGO's founder], or they owe him a favour'. ${ }^{22}$ A significant number of those interviewed indicated that informal networks are crucial in recruiting volunteers or hiring employees to work for NGOs. Talking about this issue one NGO official in Georgia said, 'Many of my employees are temporary workers. For example, the web designer [works here] ... because he owes me a favour, and X [another employee] is a friend of my friend and I would not have to pay him. ${ }^{, 23}$ Another 
interviewee in Azerbaijan confessed that many of his employees are kin members 'who need to get some [office] work experience'. ${ }^{24}$ While only a few informants brought up the issue of informality as a crucial part of relations between NGO management and their employees, most agreed when asked about the issue that informal networks are used very often in that type of relationships.

\section{Clientelism}

Patron-client relations within Azerbaijan's and Georgia's NGO sectors are sustained by the persistence of informal relations between NGOs and their donors or supporters (patrons). ${ }^{25}$ While in some cases patron-client relations function as top-down networks, enabling patronage-seeking NGOs to receive funding and political support from influential donors, in other cases clientelistic networks based on mutually beneficial exchanges of favours develop and NGOs are obliged to provide services or public goods in return for funding. As noted above, in some cases NGOs purposefully seek patronage from state institutions or officials in order to achieve some of their operational goals, such as ensuring smooth implementation of projects or securing lucrative contracts.

In Azerbaijan, patron-client relations between NGOs and the government are often legalized and are implemented through legally-created programmes. As one interviewee said:

In Azerbaijan there are these state-provided funds, which, at first sight, is exactly how it [state-society relations] should work, because it is normal for government to provide funding to civil society in certain areas which require development, but at the same time it creates the problem of dependence, the problem of government-manipulated organizations. ${ }^{26}$

This opinion is echoed by an expert from a think-tank in Brussels, who observed that 'once an NGO continuously receives funding from the government, even if originally it was not a GONGO, it becomes one - because it has to do what the government tells it to do'. ${ }^{27}$ This results in what another expert has termed 'GONGOization' of the NGO sector. That interviewee went on to explain:

When I did a study on civil society in Azerbaijan, Azerbaijanis like to say that they have these funds and they finance independent NGOs and civil society, but when you actually look through all the papers for the tenders you can see from their selection that these 'NGOs' are in fact GONGOs. ${ }^{28}$

Although the creation of GONGOs and the allocation of funding through government foundations and grants is a legal and formalized process in Azerbaijan, attempts by the state and private businesses to patronize independent NGOs are usually done informally. Moreover, as described in the previous section, many NGOs are purposefully seeking to establish patron-client networks with government officials in order to simplify their relations with the state bureaucracy and to receive patronage and 'cover' - often defined by the Russian word krysha. 
In Georgia, due to the lack of state funding and to the state's unwillingness to purposefully create pro-regime NGOs, clientelism functions 'along pro-Saakashvili and pro-Georgian Dream lines', ${ }^{29}$ resulting in NGOs siding with political parties who offer them support and patronage. One interviewee described how this type of patron-client relations - functioning through informal networking - leads to politicization of NGOs:

... for example, in Georgia when you had the change of leadership to the Georgian Dream in the government, civil society organizations, whom, before the election of Ivanishvili, you would have perceived as more independent - the very next day, people from these organizations became representatives [of Ivanishvili] in the government or parliament. That would mean that they are not independent at all and never were. ${ }^{30}$

In the words of an NGO official from Tbilisi, this re-qualification of NGO representatives into politicians

... creates another field of authoritarian ways of doing things, because when they [NGO officials] move to the government, they are worse than people who are coming from other fields. They are so authoritarian because they grew up in that environment where they were kings of these little organizations. ${ }^{31}$

A common view among interviewees - both in Azerbaijan and Georgia - was that patron-client informal networks are not only widely employed by NGO and government officials alike, but are also perceived as a fairly normal phenomenon within the NGO sector. For example, an NGO representative from Azerbaijan resented describing clientelistic networks thriving between local NGOs and the government as negative, commenting that 'we need these [funds] ... and it is much better to receive this support from our own government than from, let's say, America'. ${ }^{32}$ The same informant also explained that '...the application process [for government funds] is very straightforward and you can get [the money] almost immediately, you don't have to wait for several months, which happens when you apply for EU [funding]' 33

\section{Informal profit-making within the NGO sector}

While in the Western context, civil society is largely seen as a not-for-profit sector, which functions to provide its beneficiaries with public goods and services, in the South Caucasus, NGOs are usually understood to be for-profit organizations. ${ }^{34}$ In the words of a senior NGO official in Georgia:

NGOs are understood as professional organizations. These are not civic initiatives; for volunteers it's a job. People look at it as at a job. So sometimes they call it volunteerism, this system of interns, when young people come and do some work for free. I don't think that it is really volunteering, because the motive is their career. So it's a kind of internship, similar to interns at banks or 
ministries. These interns at NGOs are preparing for a professional career, it is not volunteering for a cause. ${ }^{35}$

Another interviewee confirms that opinion, explaining that for a vast majority of NGO employees a job at an NGO is no different from any other job:

They [people] perceive it as an opportunity to get jobs, salary and other material things. It is like being employed. For the majority, they are not interested in ecology or some other problems, but as long as they get paid for it, they can go and distribute leaflets and so on. ${ }^{36}$

Generally, the use of informal networking for personal gain appears to be widely practiced within the not-for-profit sector throughout the South Caucasus. The most commonly employed practice of profit making in the region is 'grant hunting', though this is not confined to the Caucasus (Abramson, 1999; Henderson, 2002). In the context of the Azerbaijani and Georgian NGO sectors, grant hunting is heavily dependent on the use of informal networks. The spread and the scale of this phenomenon, as described by an informant from a Georgian NGO, are enormous: 'There are many organizations which are created because there are grant opportunities available and they close down soon after. There are thousands of such organizations. ${ }^{37}$ The difference between the number of registered NGOs - thousands of which exist in both countries - and the number of actually functioning NGOs (a few dozen organizations) supports the above assumption. To make maximum income, such NGOs

... must have people experienced in making grant applications. They need to have people proficient in the English language to make a very convincing case for [international] donors. They also need to have knowledge about calls for grant proposals. Therefore, in most cases these [grant-hunters] are NGO people. Contacts and connections are very important ... you cannot do this alone. ${ }^{38}$

A very similar scenario has been described by a senior NGO official in Georgia, who explained that most such pseudo-NGOs are made up of groups of friends or colleagues:

Basically some opportunities appear and smart individuals realized that if they put together two or three people, they can create an organization and start doing things. Someone who is more educated, relatively wealthy, and representative of the middle class, these are the NGO people. ${ }^{39}$

The majority of informants in both countries confirmed that registering an NGO for the sole purpose of securing a grant and then disappearing afterwards is usually done by individuals already employed in legitimate NGOs, because 'it would be nearly impossible for someone with no NGO experience to get this [grant-hunting] done'. ${ }^{40}$ Yet, even in well-known legitimate and independent NGOs, the lack of accountability to donors and beneficiaries enables informal re-distribution of financial resources. One of the interviewees said: 'Sometimes we get more money than we actually need [to implement a 
project]. We cannot just return this money. So we have to use it for our own needs. ${ }^{41}$ In the words of an expert on South Caucasus's civil society, ${ }^{42}$ a great deal of these unused funds is spent on financing informal networks with state officials or on hiring 'volunteers'.

\section{Informal networks: Negative or positive?}

A holdover from the socialist era, the practice of using informal networks to conduct official business is omnipresent among South Caucasian civil society organizations and has survived as a result of corruption, socioeconomic inequality and injustice, and the weakness and inefficiency of formal institutions. As shown in a number of studies, the reliance on informal practices offers private safety nets that are crucial for local populations (Aliyev, 2014a), but also serves as an obstacle for institutional change and social transformation (Safiyev, 2013).

On the one hand, informal networks are used by NGO officials and representatives to circumvent complex and often corrupt state bureaucracies. Not only in the highly corrupt state institutions of Azerbaijan, but also in the recently reformed and largely freed from corruption Georgian institutions, the reliance on informal networks is critical for accessing services or receiving preferential treatment. It is noteworthy that this rule applies not only to NGOs, but also to most other organizations and individuals approaching formal institutions. The majority of those interviewed for this article representatives and officials of NGOs in Azerbaijan and Georgia, as well as senior EU officials - admitted that building and maintaining informal relations with state officials is indispensable for the successful implementation of projects in the region. For local NGOs, the use of informal networks facilitates access to donations and contributions, which, in the long term, assist organizational sustainability and, in the short term, assist NGOs in effective implementation of projects. Using informal connections and networks in the daily work of NGOs helps NGO functionaries to collaborate with other organizations and to cement their position within communities. For example, one NGO official in Azerbaijan stated that 'most people in the mahalla [community] where we work know me personally and when ... [NGO employees] need to get some work done in the neighbourhood, they just mention my name and people always cooperate'. ${ }^{43}$ Clientelistic networks are similarly beneficial. Maintaining patron-client relations with powerful and influential political or business elites allows NGOs to access funding, to navigate the complexities of state bureaucracy, and to avoid paying bribes. As one interviewee put it, 'If I did not have connections with important people, I would have to pay a lot of bribes, and I would spend a lot of time waiting to get all the papers [permits] I need. You cannot [easily] run an organization without patrons.' 44

On the other hand, the use of informal networks leads to unequal distribution of scarce resources, enabling the better connected NGOs to access funding that is otherwise inaccessible to less-well-connected organizations. In the words of an official from a European NGO working with civil society in the South Caucasus: 'There is always a catfight among NGOs for grants. And only the most powerful NGOs with a lot of [informal] networks usually succeed [in securing the funds]. ${ }^{, 45}$ The use of clientelistic networks not only politicizes NGOs, but also undermines their ability to function as 
watchdogs and, even more so, their chances of maintaining independence from politics and business interests. Furthermore, as revealed by interviewees, informal networking functions as an important mechanism supporting and encouraging the phenomenon of 'grant hunting'. Having employed their well-developed, intricate, informal networks for the purpose of 'grant hunting', some NGO representatives continuously succeed in securing grants therefore encouraging the practice to flourish on an enormous scale.

The pros and cons of the use of informal connections within the NGO sector are manifold. As suggested by Ledeneva (2012, p. 375), the use of informal networking 'is context-bound - it can be equally positive, neutral, or negative'. While mostly seen as negative, corrupt, or detrimental in Western contexts, in the South Caucasus, informality is understood as part of daily life, as a necessity, and as a social tool. Therefore, the majority of individuals in Azerbaijan and Georgia, both within the NGO sector and beyond, perceive the use of informal networks as a social mechanism which has both positive and negative sides.

\section{Conclusion}

The empirical examination of informal relations within Azerbaijani and Georgian NGO sectors conducted by this study reveals that informality - conducting official relations on an informal level--constitutes an important and, at times, inseparable part of the NGOs' working environment. Data from interviews carried out with NGO officials and representatives show a consistent pattern of reliance on informal networks by the NGO sectors of Azerbaijan and Georgia. Informal connections and contacts are used by NGO staff in the same way that they are used by representatives of other institutions: that is, informality manifests itself in their dealings with state officials. This study has confirmed the findings of Grødeland and Aasland (2011, p. 130) concerning NGO officials in Central Eastern Europe and the Balkans in that their 'mindsets and their behaviour have therefore been shaped by the same set of norms that influence the perceptions and behaviour of those of the public at large'. Along with confirming the already known trends in informal relations within the post-communist NGO sectors - such as the spread and importance of informal networking - the empirical findings in this study also show that informal networking within the Azerbaijani and Georgian NGO sectors is used to construct and maintain clientelistic networks instrumental for the NGOs' success. In addition, informal networks serve as mechanisms of informal profit-making within the NGO sector enabling a small but resourceful clique of NGO representatives to employ their private networks for 'grant hunting'. Taken together, the findings of this study enhance our knowledge about the reliance on informality within post-Soviet NGO sectors. Regardless of differences between Azerbaijani and Georgian NGO sectors, informality manifests itself in similar ways among the NGOs of these two countries, and the reliance on informal networks is similarly widespread. In particular, the extensive institutional reforms recently implemented in Georgia, in spite of reducing the influence of corruption and bribery, have not succeeded in weakening the importance of informal networking. Though this suggests that the role of informality in Azerbaijan and Georgia may not be too different than it is in other post-Soviet countries, further research is needed to support this assumption. 
The findings of this study present a couple of important implications for future research. Firstly, the use of informal networks within the NGO sectors of post-Soviet countries like Georgia and Azerbaijan is likely to survive and thrive as long as informality is employed by other formal institutions and, most of all, as long as it is accepted and approved by state officials of post-Soviet countries. Secondly, the reliance on informality allows NGOs to compensate for the deficiencies in their operational environment - scarce funding, competition, lack of popular participation - and the weaknesses of their organizational structure. Accordingly, improving the working environment of NGOs and increasing the awareness among NGO officials and representatives about the purpose and objectives of civil society may help to reduce the negative role of informal networking within NGO sectors.

\section{References}

Abbasov, S. (2010) Civil Society in Azerbaijan: Under Fire but Still Resisting, Caucasus Analytical Digest, 22(12), pp. 13-16.

Abramson, D. (1999) A critical look at NGOs and Civil Society as means to an end in Uzbekistan, Human Organization, 58(3), pp. 240-250.

Aliyev, H. (2014a) Civil Society in the South Caucasus: Kinship Networks as Obstacles to Civil Participation, Journal of Southeast European and Black Sea Studies, 14(2), pp. 263-282.

Aliyev, H. (2014b) The Effects of Saakashvili's Era Reforms on Informal Practices in the Republic of Georgia, Studies of Transitional States and Societies, 6(1), pp. 21-35.

Belli, P., Gotsadze, G. \& Shahriari, H. (2004) Out-of-pocket and informal payments in health sector: Evidence from Georgia, Health Policy, 70(1), pp. 109-123.

Böröcz, J. (2000) Informality and Nonprofits in East Central European Capitalism, Voluntas: International Journal of Voluntary and Nonprofit Organizations, 11(2), pp. 123-140.

Börzel, T. \& Pamuk, Y. (2011) Pathologies of Europeanization Fighting Corruption in the Southern Caucasus, West European Politics, 35(1), pp. 79-97.

Bunce, V. (2003) Rethinking Recent Democratization Lessons from the Postcommunist Experience, World Politics, 55(2), pp. 167-192.

Burnham, P., Grant, W., Lutz, K. G., \& Layton-Henry, Z. (2008) Research methods in politics (Basingstoke: Palgrave Macmillan).

Coalson, R. (2014) Azerbaijan tightens screws on civil society, independent media, Radio Free Europe/Radio Liberty, September 09, 2014.

Demes, P. \& Forbrig, J. (2007) Civic Action and Democratic Power Shifts: On Strategies and Resources, in Forbrig, J. \& Demes P. (Eds.), Reclaiming Democracy: Civil Society and Electoral Change in Central and Eastern Europe, pp. 175-190 (Washington, DC: The German Marshall Fund of the United States).

Dershem, L. \& Gzirishvili, D. (1998) Informal Social Support Networks and Household Vulnerability: Empirical Findings from Georgia, World Development, 26(10), pp. 1827-1838.

Diuk, N. (2012) The Next Generation in Russia, Ukraine and Azerbaijan. Youth, Politics, Identity and Change (Lanham, MA: Rowman and Littlefield Publishers). 
Engvall, J. (2012) Against the Grain: How Georgia Fought Corruption and What It Means (Washington DC: Central Asia-Caucasus Institute).

Evans, A., Henry, L., \& Sundstrom, L. (Eds.) (2006) Russian civil society: A critical assessment (Armonk, NY: M.E. Sharpe).

Evenson, K. (2007) GONGO Trends and Transformations (Washington DC: USAID).

Gibson, J. (1998) Social Networks and Civil Society in Process of Democratization (Glasgow: Centre for the Study of Public Policy, University of Strathclyde).

Grødeland, A. \& Aasland, A. (2011) Civil Society in Post-Communist Europe: Perceptions and Use of Contacts, Journal of Civil Society, 7(2), pp. 129-156.

Guliyev, F. (2012) Political Elites in Azerbaijan, in Heinrich A. \& Pleines H. (Eds.) Challenges of the Caspian Resource Boom. Domestic Elites and Policy-Making, pp. 117-131 (Basingstoke: Palgrave Macmillan).

Hemment, J. (2004) The Riddle of the Third Sector: Civil Society, International Aid, and NGOs in Russia, Anthropological Quarterly, 77(2), pp. 215-241.

Henderson, S. (2002) Selling Civil Society: Western Aid and the Nongovernmental Organization Sector in Russia, Comparative Political Studies, 35(2), pp. 139-167.

Howard, M. (2003) The Weakness of Civil Society in Post-Communist Europe (Cambridge: Cambridge University Press).

Ishkanian, A. (2008) Democracy Building and Civil Society in post-Soviet Armenia (New York, NY: Routledge).

Keeley, B. (2007) Human Capital. How What You Know Shapes Your Life (Paris: OECD).

Khutsishvili, G. (2009) Georgia's Degenerative Transition, in Emerson, M. \& Youngs, R. (Eds.), Democracy's Plight in the European Neighbourhood, pp. 68-76 (Brussels: Centre for European Policy Studies).

Ledeneva, A. (2012) Informality and Informal Politics, in Gill, G. \& Young, J. (Eds.) Routledge Handbook of Russian Politics and Society, pp. 375-386 (London: Routledge).

Ledeneva, A. (2013) Can Russia Modernize? Sistema, Power Networks and Informal Governance (Cambridge: Cambridge University Press).

Miller, W., Koshechkina, T. \& Grødeland, Å. (1997) How Citizens Cope with Postcommunist Officials: Evidence from Focus Group Discussions in Ukraine and the Czech Republic, Political Studies, 45(3), pp. 597-625.

Morris, J. \& Polese A. (Eds.) (2014) The Informal Post-Socialist Economy: Embedded Practices and Livelihoods (London: Routledge).

Nodia, G. (2005) Civil Society Development in Georgia: Achievements and Challenges (Tbilisi: Caucasus Institute for Peace, Democracy and Development).

Putnam, R. (1993) Making Democracy Work. Civic Traditions in Modern Italy (Ithaca, NJ: Princeton University Press).

Rose, R. (1994) Postcommunism and the Problem of Trust, Journal of Democracy, 5(3), pp. 18-30.

Rose, R. (2000) Getting Things Done in Anti-modern Society: Social Capital Networks in Russia, in Social Capital. A Multifaceted Perspective, Dasgupta P. \& Serageldin I. (Eds.), pp. 147-172 (Washington DC: International Bank for Reconstruction and Development). 
Round, J. \& Williams, C. (2010) Coping with the social costs of 'transition': Everyday life in post-Soviet Russia and Ukraine, European Urban and Regional Studies, 17(2), pp.183-196.

Safiyev, R. (2013) Informality in a Neopatrimonial State: Azerbaijan, in Giordano, C. \& Hayoz, N. (Eds.) Informality in Eastern Europe: Structures, Political Cultures and Social practices, pp. 433-450 (Bern: Peter Lang).

Uhlin, A. (2006) Post-Soviet Civil Society: Democratization in Russia and the Baltic States (London: Routledge).

USAID. (2013) 2012 CSO Sustainability Index for Central and Eastern Europe and Eurasia (Washington DC: USAID).

Walker, C. \& Habdank-Kołaczkowska, S. (2013) Nations in Transit. Fragile Frontier: Democracy's Growing Vulnerability in Central and Southeastern Europe (Washington DC: Freedom House).

Williams, C., Round, J \& Rodgers, P. (2013) The Role of Informal Economies in the Post-Soviet World. The End of Transition? (London: Routledge).

\section{Endnotes}

${ }^{1}$ This study focuses primarily on formal civil society organizations known under the term 'nongovernmental organizations' (NGOs). NGOs are understood here as independent, legally registered organizations, existing and operating in the public sphere, and different from political organizations, state institutions, and the market.

2 'Informal networks' are the circles of individuals assisting or cooperating with each other for their mutual benefit. Informal networks can be analysed through the lens of a broader concept of social capital, defined by the OECD as 'networks together with shared norms, values, and understandings that facilitate co-operation within or among groups' (Keeley, 2007, p.103). However, the concept of social capital covers a variety of groups, associations, and organizational structures, some of which are not necessarily informal, such as grassroots organizations or interest clubs (Putnam, 1993). With that in mind, this study limits its conceptual scope to the concept of 'informal network', which allows for a more contextualized analysis of informality within civil society.

3 According to the Caucasus Barometer representative survey conducted in 2011, only $6 \%$ of respondents in Azerbaijan and $4 \%$ in Georgia participated in the work of civil society organizations.

${ }^{4}$ All interviews were conducted in confidence, and the names or organizational affiliations of interviewees are withheld by mutual agreement.

${ }^{5}$ The majority of interview participants believed that the actual number of independent and active NGOs, employing at least six full-time staff members, is fewer than 50 in Georgia and fewer than 30 in Azerbaijan. A similar observation has been made by Nodia (2005, p. 20).

${ }^{6}$ On average around 200 new NGOs are registered every year in Azerbaijan.

7 The NGO Sustainability Index (a seven-point scale, with 1 for highest and 7 for lowest sustainability levels), compiled by USAID (2013), assigned the Azerbaijani and Georgian NGO sectors similar sustainability scores: 4.7 for Azerbaijan and 4.2 for Georgia.

${ }^{8}$ One of the largest state-controlled civil youth organizations in Azerbaijan is the pro-regime youth movement 'Ireli'.

${ }^{9}$ Official of a European NGO, interview, Brussels, 9 July 2013. 
${ }^{10}$ Official at the European Commission, interview, Brussels, 11 July 2013.

${ }^{11}$ Official of a European NGO, interview, Brussels, 9 July 2013.

12 According to the Nations in Transit (NIT) project (Walker \& Habdank-Kołaczkowska, 2013), since 2003 Georgia's civil society has managed to achieve significant liberalisation.

${ }^{13}$ NGO official, interview, Baku, 18 February 2014.

${ }^{14}$ NGO official, interview, Tbilisi, 9 September 2013.

${ }^{15}$ NGO representative, interview, Tbilisi, 7 September 2013.

${ }^{16}$ NGO official, interview, Baku, 7 March 2014.

${ }^{17}$ European Union official, interview, Tbilisi, 13 September 2013.

${ }^{18}$ NGO official, interview, Tbilisi, 10 September 2013.

${ }^{19}$ NGO official, interview, Tbilisi, 3 September 2013.

${ }^{20}$ NGO official, interview, Tbilisi, 10 September 2013.

${ }^{21}$ NGO representative, interview, Baku, 14 August 2013.

${ }^{22}$ NGO representative, interview, Tbilisi, 11 September 2013.

${ }^{23}$ NGO official, interview, Tbilisi, 18 September 2013.

${ }^{24}$ NGO official, interview, Baku, 5 August 2013.

${ }^{25}$ Given that the influence of Western donors on South Caucasian NGOs is very unequal; this study focuses primarily on patron-client relations between NGOs and their local donors. While foreign donors continue to play an important part in the financing of Georgian NGOs, a series of stringent NGO laws recently adopted by the Azerbaijani government has limited the role of foreign donors in that republic (Coalson, 2014). Yet even in Georgia the role of informal networks in patron-client relations between local NGOs and their foreign donors is rather limited, because informal networks are normally employed to cement relationships with local actors rather than being used in relations with international funding agencies. Undoubtedly, the availability of grants increases the benefits of 'grant-hunting'. However, in contrast to local patrons of civil society, international donors do not engage in informal relations with NGOs and therefore the use of networks in collaboration between local NGOs and foreign finding agencies is insignificant.

${ }^{26}$ Official of a European NGO, interview, Brussels, 10 July 2013.

${ }^{27}$ Expert from a European think-tank, interview, Brussels, 12 July 2013.

${ }^{28}$ Official of a European NGO, interview, Brussels, 9 July 2013.

${ }^{29}$ Expert from a European think-tank, interview, Brussels, 15 July 2013.

${ }^{30}$ Official of a European NGO, interview, Brussels, 9 July 2013.

${ }^{31}$ NGO official, interview, Tbilisi, 10 September 2013.

${ }^{32}$ NGO representative, interview, Baku, 5 March 2014.

${ }^{33}$ Ibid.

${ }^{34}$ In the South Caucasus, due to the general lack of understanding of the concept of civil society, and owing to the lavish funding that NGOs receive from their foreign donors, civil society work and volunteer work are closely associated with personal gain or profit-making.

${ }^{35}$ NGO official, interview, Tbilisi, 12 September 2013.

${ }^{36}$ NGO official, interview, Tbilisi, 18 September 2013.

${ }^{37}$ NGO representative, interview, Tbilisi, 5 September 2013.

${ }^{38}$ NGO representative, interview, Baku, 12 August 2013.

${ }^{39}$ NGO official, interview, Tbilisi, 10 September 2013.

${ }^{40}$ NGO representative, interview, Tbilisi, 5 September 2013.

${ }^{41}$ NGO representative, interview, Baku, 11 August 2013.

${ }^{42}$ Expert from a European think-tank, interview, Brussels, 15 July 2013.

${ }^{43}$ NGO official, interview, Baku, 7 August 2013.

${ }^{44}$ NGO official, interview, Baku, 5 August 2013.

${ }^{45}$ Official of a European NGO, interview, Brussels, 9 July 2013. 